\title{
A imagística da escrita nos extremos da obra de Clarice Lispector
}

Paulo Ricardo Becker*

Vinícius Linné

\section{Resumo}

O presente artigo baseia-se na obra $A$ imagística de Shakespeare, de Caroline Spurgeon (2006), cuja finalidade foi reunir, catalogar e analisar todas as metáforas presentes na obra do clássico escritor inglês. Neste caso, porém, serão analisadas apenas as metáforas, os símiles, as comparações e as referências acerca da escrita e da criação literária contidos nos dois extremos da produção de Clarice Lispector. Ou seja, de um lado, será considerado Perto do coração selvagem (1998b), publicado pela primeira vez em 1964, e Um sopro de vida: pulsações (1999), publicado pela primeira vez em 1978. Para isso, será utilizado o método de Análise de conteúdo, desenvolvido por Bardin (2011), no qual a análise textual é feita de modo quantitativo e qualitativo. Assim, as imagens são grifadas, reunidas, categorizadas e ponderadas conforme sua frequência de aparição. O objetivo é verificar como a temática da criação literária progrediu ao longo da produção da autora, além de explorar a representação de maior relevância para Lispector: a demiurgia, tratada aqui com base nas teorias de Austin (1990) e Cassirer (2009).

Palavras-chave: Análise de conteúdo. Criação literária. Demiurgia. Gênesis.

\section{Introdução}

Todos os escritores de ficção, cedo ou tarde, deparam-se com a pergunta: por que você escreve? A resposta é sempre subjetiva. É preciso, neste momento, alcançar o inexplicável. Por íntimo comando, como autoanálise, para exorcizar demônios, para ganhar dinheiro, para obter a imortalidade. Muitas são as alternativas possíveis, nenhuma garante, porém, o sentimento de que a pergunta foi plenamente respondida. Em uma de suas últimas entrevistas, por exemplo, Clarice Lispector rebateu essa questão com outra: "Por que você bebe água?".

Ao fazê-lo, a autora comparou a necessidade de escrever a uma das necessidades mais intrínsecas à sobrevivência humana. Beber água é vital. Escrever

Doutor. Professor, integrante do Programa de Pós-Graduação em Letras da Universidade de Passo Fundo. E-mail: paulobecker@via-rs.net

** Doutorando do Programa de Pós Graduação em Letras da Universidade de Passo Fundo. E-mail: vinicius. linne@gmail.com

Data de submissão: 12/07/2017 - Data de aceite: ago. 2017 http://dx.doi.org/10.5335/rdes.v13i2.7242 
também o é? Para Lispector sim. Mas por quê? A questão que ela própria já recebia com uma certa impaciência sempre rondou as entrevistas que fez com outros escritores. Além disso, a escrita é, justamente, um de seus temas recorrentes.

De fato, à crítica literária, aos acadêmicos e teóricos, cabe a análise da obra finalizada, sua estrutura e efeitos nos leitores. A própria crítica genética é responsável pelo estudo da composição de uma obra, detendo-se muito mais na evolução do processo de escrita, além das alterações mais significativas feitas pelo autor, do que propriamente nos motivos para a existência da criação literária.

Sendo assim, a preocupação acerca das razões para a criação está contida, especialmente, nos próprios autores. Nasce, assim, um texto metalinguístico de escritores fascinados com o mistério das letras. Entre eles, poucos exploraram tanto o tema quanto Lispector. Por tornar perceptível esse traço, sua obra se revela como uma fonte abundante para compreender as razões que levam alguém a criar com palavras algo que, já de acordo com o pensamento da Arte pela Arte, é inútil fora de si mesmo.

Partindo de tais pressupostos, percebe-se que não há teorias canônicas que deem conta dos motivos para a criação ficcional. Opta-se, assim, por buscar respostas possíveis na obra de uma escritora extremamente envolvida com as representações da ficção. Por isso, recorre-se à imagística da escrita em Clarice Lispector como tema deste artigo.
Para tanto, consideram-se os conceitos empregados por Caroline Spurgeon (2006) em uma pesquisa pioneira quanto à análise literária: A imagística de Shakespeare. Sua tese coletou e analisou todas as metáforas presentes na obra do clássico escritor inglês, a fim de melhor compreender sua escrita e sua personalidade. Este artigo, por sua vez, pretende realizar algo similar na obra de Clarice Lispector, delimitando, porém, sua área de abrangência: coletando e categorizando apenas as imagens, ou seja, símiles, comparações e metáforas sobre a escrita, a palavra e o ato da criação.

Devido à extensão deste trabalho, para a análise serão selecionados apenas os dois extremos da obra clariciana. Seu primeiro romance, Perto do coração selvagem (1998b), lançado em 1944, e a ficção póstuma Um sopro de vida: pulsações (1999), publicado em 1978. Em estudos posteriores, serão considerados os demais romances, bem como os contos e as crônicas da autora, a fim de se obter um material considerável.

Sobre as obras, é importante destacar que sua riqueza literária e suas muitas nuances fazem com que Lispector seja uma das autoras mais pesquisadas no Brasil. Apesar disso, julga-se haver muito a extrair de suas composições, especialmente no tocante à criação literária. Geralmente, os pesquisadores destacam a relevância do intimismo em sua obra, as epifanias presentes, a representação da mulher, entre outros itens mais aparentes. 
O trabalho considerado o mais completo no âmbito da análise literária, pelo menos pelo Instituto Moreira Sales, que mantém o acervo da autora, é a tese defendida no ano de 2000 na Universidade do Minho, em Portugal, por Carlos Mendes de Sousa (2012). A pesquisa, intitulada Clarice: figuras da escrita, dá conta de reunir sobre verbetes e elucidar com teorias da literatura, da filosofia e da psicanálise diversas imagens presentes na ficção clariciana. Os assuntos vão desde galinhas até guindastes e buscam justificar o imaginário de Lispector.

Ainda assim, tal pesquisa não aprofunda a imagística acerca da criação ficcional, objetivo geral deste trabalho, além de não quantificar seus achados, a fim de demonstrar a representatividade de cada um. Dessa forma, verifica-se uma lacuna tanto nas teorias sobre os motivos da criação quanto nos trabalhos já existentes acerca da imagística da escrita em Clarice Lispector.

Diante de tudo isso, acredita-se que, ao se conhecer os porquês da arte de Lispector, é possível experimentar um novo olhar sobre sua obra, redistribuindo conceitos e funções a certos elementos de sua narrativa. Outrossim, esta pesquisa tem a pretensão de contribuir com as discussões sobre a criação literária como um todo, demonstrando que, ao contrário do que pensava Kant, a arte tem uma utilidade além do efeito estético, nem que seja para seu autor. Assim, os motivos elencados para a criação de Lispector, através de sua imagística, podem responder, em grande parte, à pergunta "Por que você escreve?", mesmo quando feita a outros autores, inclusive ao desta pesquisa.

A fim de atingir os objetivos propostos, a metodologia empregada é similar à utilizada por Caroline Spurgeon. Além disso, alia-se outro importante método analítico, cuja teoria foi publicada somente 42 anos depois de A imagística de Shakespeare. Trata-se do livro Análise de conteúdo, proposta por Laurence Bardin (2011), na qual o corpus é dissecado, a fim de fornecer diferentes categorias e permitir uma avaliação quantitativa $\mathrm{e}$ qualitativa dos aspectos avaliados.

Assim, os procedimentos adotados preveem, de início, a leitura das obras de Lispector em ordem cronológica, destacando e registrando cada uma das referências relacionadas à escrita, à criação literária e às palavras. É importante destacar que as imagens que possuem ligação com o ofício da criação artística também serão consideradas, uma vez que muitas personagens de Lispector usam a pintura ou a escultura como forma de arte análoga à escrita.

Posteriormente, todas as imagens reunidas serão catalogadas, observando os temas recorrentes, a fim de classificá-las de acordo com as comparações realizadas. Como meros exemplos de categorias, podem-se citar: catarse, autoconhecimento e demiurgia.

A partir desse ponto, serão elaborados gráficos para uma melhor visualização da predominância de certas imagens, bem como da evolução das concepções de escrita no decorrer da obra da autora. Serão analisadas, assim, além das imagens mais 
frequentes, quais concepções Lispector mudou ao longo de seus escritos e como essas concepções moldaram sua produção.

É imprescindível destacar que toda leitura, pesquisa e catalogação conduzirão, ainda, à análise da principal representação da escrita à luz das teorias acerca da criação literária e da mitologia referente à palavra. De fato, faz-se necessário esclarecer que essa pesquisa não partiu de uma teoria una ou inequívoca em busca de exemplos textuais que a ilustrassem. Tendo em vista a metodologia empregada, o marco teórico foi definido a posteriori pelas categorias e imagens avaliadas na obra de Lispector.

Sendo assim, como ponto de partida, o primeiro item apresenta o conceito de imagem elaborado por Paz (1982), entendendo que, da mesma forma que um poeta, Lispector utiliza de metáforas, símiles, comparações e outras figuras de linguagem não para representar algo, mas para criar um novo conceito, que não pode ser submetido a uma avaliação de verdadeiro ou falso, possível ou impossível. A esse conceito somam-se as ideias de Bachelard (1988) acerca de representação do interior e do devaneio, sobretudo aquele ligado à criação. Além disso, a técnica empregada na pesquisa é esmiuçada, esclarecendo os principais pontos da Análise de Conteúdo, além das escolhas realizadas nos casos em que foi necessária uma avaliação mais profunda das categorias elencadas.

Por fim, apresenta-se um panorama de como a imagística da escrita ocupou a ficção de Lispector, ganhando representação com o passar do tempo, além de apresentar gráficos que permitem visualizar todo este processo. Os resultados incluem, ainda, a exploração de uma das categorias, a mais relevante para a imagística da escrita de Lispector nas duas obras: a demiurgia.

\section{A imagem como expressão do indizível}

É, principalmente, através das figuras de linguagem que um texto pode ganhar literariedade, adquirindo um sentido conotativo até então inexprimível pela sintaxe usual. O campo em que mais se utilizam essas figuras é, sem dúvida, o poético. Assim, à primeira vista, pode parecer um contrassenso analisar tais elementos na composição de Lispector, uma vez que a escritora produziu apenas prosa durante sua carreira literária. Por isso, antes de definir o conceito de imagem, é essencial evocar o conceito de poema proposto por Paz:

O poema não é uma forma literária, mas o lugar de encontro entre a poesia e o homem. O poema é um organismo verbal que contém, suscita ou emite poesia. [...] Todas as atividades verbais, para não abandonar o âmbito da linguagem, são susceptíveis de mudar de signo e se transformar em poemas: desde a interjeição até o discurso lógico. [...] Classificar não é entender. E menos ainda compreender. Como todas as classificações, as nomenclaturas são instrumentos de trabalho. No entanto, são instrumentos que se tornam inúteis quando queremos empregá-los para tarefas mais sutis do que a simples ordenação externa (1982, p. 17). 
Por esse ponto de vista, é possível perceber que mesmo a prosa pode ser enquadrada como poética, desde que expanda a linguagem usual, transformando-a em uma ferramenta de encontro entre a poesia ${ }^{1}$ e o homem. De fato, em Lispector a escrita adquire uma subjetividade e uma expressão íntima de tal forma a garantir esse encontro. Como escreve Coutinho: "Trechos seus indicam uma aguda percepção de detalhe, que têm como condição o desmantelo da lógica prosaica e a construção de uma prosa mais afim do poético" (1999 p. 530).

Assim, uma vez que as sensações são de difícil expressão através de palavras e conceitos comuns, a autora opta por expressá-las através de imagens, criando uma rica fonte de estudos nesse sentido. Como imagem aqui se entende todo tipo de figura de linguagem que ilustre um conceito, da mesma forma que Spurgeon considera que:

Uso o termo "imagem" aqui como a única palavra à minha disposição para cobrir todas as espécies de símiles, bem como todos os tipos daquilo que é na verdade um símile compactado - a metáfora. Sugiro que dispamos nossas mentes da lembrança de que $o$ termo carregue em si apenas imagens visuais, e pensemos nele, para os fins em vista, como conotativo e todo e qualquer quadro imaginativo ou outra experiência, desenhado de todo e qualquer modo, que possa ter ocorrido ao poeta, não só por meio de seus sentidos, mas também através de sua mente e emoções, e que ele usa em forma de símile ou metáfora, no sentido mais amplo desses termos, para fins de analogia (2006, p. 05).

Essa definição enquadra-se bem nos objetivos do trabalho, uma vez que não se pretende classificar as figuras de linguagem presentes em cada citação, mas sim estudar o sentido que elas atribuem à escrita. $\mathrm{O}$ próprio conceito de imagem poética não se restringe ao trabalho de Spurgeon. Paz o apresenta de forma muito similar:

A palavra imagem possui, como todos os vocábulos, diversas significações. [...] Convém advertir, pois, que designamos com a palavra imagem toda forma verbal, frase ou conjunto de frases, que o poeta diz e que, unidas, compõem um poema. Essas expressões verbais foram classificadas pela retórica e se chamam comparações, símiles, metáforas, jogos de palavras, paronomásias, símbolos, alegorias, mitos, fábulas, etc. Quaisquer que sejam as diferenças que as separam, todas têm em comum a preservação da pluralidade de significados da palavra sem quebrar a unidade sintática da frase ou do conjunto de frases (1982, p. 119).

As imagens, assim, dão um sentido performático à língua, fazendo-a deixar de ser mera representação da realidade, para criar novas perspectivas e visões de mundo. Por isso, ainda segundo Paz (1982, p. 120), a poesia não pode ser submetida a uma verificação de verossimilhança, baseada na contraposição de verdadeiro $\mathrm{x}$ falso.

Sendo assim, quando Lispector afirma que: "Escrever é uma pedra lançada no poço fundo" (1999, p. 14), por exemplo, o que ela faz não é meramente imitar ou descrever a realidade, mas criar um conceito que até então não existia. $\mathrm{Ou}$ realizar o que $\mathrm{Paz}$ (1982, p. 120) descreve como submeter à unidade a pluralidade do real. Desse modo, ao aproximar dois conceitos destoantes, a criação de 
imagens poéticas serve para expressar o mundo de uma forma mais plena do que se conseguiria pela linguagem usual.

É justamente em tais imagens que os conceitos mais fundamentais sobre a escrita e a criação artística são expressos na obra de Lispector. Não sendo possível responder de forma simples porque escrevia, a autora faz de sua obra uma longa explicação poética. Nesse sentido, é importante considerar o que afirma Bachelard:

A imagem poética nova - uma simples imagem! - torna-se assim, simplesmente, uma origem absoluta, uma origem de consciência. Nas horas de grandes achados, uma imagem poética pode ser o germe de um mundo, o germe de um universo imaginado diante do devaneio de um poeta (1988, p. 01).

Através da criação de novas imagens, Lispector dá origem a todo um universo que expande a compreensão da escrita, de seus sentidos e representações. Assim, muito além da metalinguagem, ou de uma escrita autorreferencial, o que se tem é o esforço de se alcançar uma representação mais verdadeira do real, inexpressível de outro modo que não o da poesia.

Sendo assim, com base no conceito de imagem proposto por Paz, mais do que um simples rebuscamento ou enfeite, a imagem é uma forma própria de expressar o conceito que de outra forma não se alcança. Chega-se, assim, a um aspecto interessante da linguagem própria e do estilo de cada escritor. Segundo Spurgeon, a imagística de um autor é usada de forma mais instintiva do que racional:
[...] é uma revelação em grande parte inconsciente, que tem lugar em momentos de sentimentos exacerbados, do equipamento de sua mente, dos canais de seus pensamentos, da qualidade das coisas, dos objetos e incidentes que ele observa e lembra e, talvez mais significativo do que tudo, daqueles que ele não observa e não lembra (2006, p. 05).

A autora propõe, entre outros elementos, que a imagística de cada escritor está plenamente condicionada ao que ele conhece, observa e experimenta. Por meio da análise dessas imagens, seria possível, portanto, inferir os conhecimentos que o autor possui sobre esses ou aqueles aspectos que utiliza como metáforas.

Sugiro que seja justificado pressupor que, no conjunto de sua obra, o poeta terá a tendência de extrair uma considerável percentagem de suas imagens dos objetos que ele melhor conhece, ou a respeito dos quais mais pensa, ou dos incidentes que vivenciou (SPURGEON, 2006, p. 11).

Diferentemente de outros métodos, em que as citações são utilizadas como exemplos de uma certa perspectiva ou para a iluminação de teorias, no estudo de Spurgeon, as imagens são analisadas por seu próprio valor semântico. Dessa forma, são ampliados os estudos da obra de Shakespeare, além de serem fornecidas revelações sobre o autor, bem como sobre os temas e tons de suas composições.

Tal método de análise aplica-se perfeitamente à obra de Clarice Lispector. Afinal, a escritora, como se sabe, é classificada de Intimista, ou seja, em seus escritos, as sensações e os pensamentos íntimos são mais importantes do que os 
fatos em si. Discorrendo sobre esta manifestação literária, pode-se concordar com Moisés no sentido de que:

[...] o intimismo de Clarice Lispector distingue-se do desses precursores [Guimarães Rosa e Cornélio Pena] e modelos em ser suprapsicológico ou supra-introspectivo, resultante que é da detecção das ondas submersas do "eu" ou das relações dos "eus" entre si que refogem ao olhar analítico do ser humano em geral. Intimismo de místico acento, mas não metafísico; nela inexiste o mito, salvo se entendermos por isso o profundamente humano, o assombro pela Vida, ou a obsessão pelo "eu”. É com a lente da fantasia, da adivinhação, da magia, que ela tem acesso, e nós com ela, ao universo interiorizado de cada um de nós (2004, p. 357).

De fato, na obra da autora, os acontecimentos e o transcurso natural das histórias aparecem de forma muito esparsa. Os fatos concretos são deixados em detrimento do que eles causam. Para Lispector, o que importa é o que se passa dentro das personagens, seus pensamentos íntimos e filosóficos, ou o que Campedelli expressa como "o ambíguo espelho da mente" (1981, p. 103), no qual o narrador penetra na consciência das personagens, rompendo os limites entre um e outro.

Fugindo ao típico enredo e às personagens comuns, Lispector não poderia ser diferente no que diz respeito à linguagem. Por trás de vocabulários simples, a autora é capaz de brincar com as palavras, renovando seus sentidos e usando-as a bel-prazer, a fim de expressar conceitos pouco usuais.

Além disso, Lispector se utiliza da linguagem para questionar a própria linguagem, colocando-a como ineficiente para ilustrar certos pensamentos ou emoções, chegando muitas vezes a torná-la nua, dispensável.

Eu queria escrever um livro. Mas onde estão as palavras? esgotaram-se os significados. [...] Sou um escritor que tem medo da cilada das palavras: as palavras que digo escondem outras - quais? talvez as diga. [...] Meu vocabulário é triste e às vezes wagneriano-polifônico-paranóico. Escrevo muito simples e muito nu. [...] Este é um livro silencioso. E fala, fala baixo (LISPECTOR, 1999, p. 14).

Sua escrita "simples" é capaz de, segundo Coutinho (1999), conduzir a um engano: apesar da aparente simplicidade, o arranjo das palavras permite uma complexidade infinita de pensamentos e sentidos. Sua recomposição semântica parece navegar no sentido de encontrar definição ao que não é possível exprimir com as expressões usuais. Sendo assim, para Lispector, a palavra é uma possibilidade infinita que tenta capturar o pensamento e o instante.

Uma linguagem refletindo incessante vaivém de perguntas enquanto não houver respostas, a linguagem de Clarice não aceita "retrocessos", não aceita "correções", pois é toda ela tecida no impulso ímpar dos instantes vividos na experiência, e esses instantes, passados os seus momentos, não admitem retorno: é o autor escrevendo a sua obra à medida que se lê e lê a sua realidade: no instante em que a autor leu em si mesmo a sua realidade cotidiana, alguma coisa "se escreveu" (NOVELLO, 1987, p. 63).

Desta forma, buscando respostas, a escrita de Lispector inscreve em si a própria autora, registrando no papel os caminhos subjetivos de uma mente cria- 
dora, transcrevendo questionamentos e representações sobre $o$ ato da criação literária. Assim, destaca-se a importância da metalinguagem, presente em toda obra de Lispector.

A metalinguagem, como afirma Chalhub (1988), ocorre quando a obra literária contempla a si mesma, descreve sua construção, ou, ainda em outros termos, quando as palavras são utilizadas para promover a reflexão sobre as próprias palavras. Um desdobrar-se dentro de si e fora, ao mesmo tempo. Um jogo em casa de espelhos, como é, de fato, a obra de Lispector.

Parece bastante comum em Clarice Lispector o desejo de penetrar nos mistérios da criação, não excluindo a curiosidade de verificar como isso ocorreria na obra alheia, inclusive através das palavras dos próprios autores, na tentativa de buscar os diferentes "modos" de criar pela literatura. [...] Em suas perguntas, na qualidade de repórter, a diversos artistas, nota-se essa inquietação diante da obra, diante da coisa criada (NOVELLO, 1987, p. 66).

A primeira frase de seu romance inaugural, Perto do Coração Selvagem, já introduz a temática da escrita: "A máquina do papai batia tac-tac... tac-tac-tac..." (LISPECTOR, 1998b, p. 13). Independentemente de alguém que a manipule, a máquina de escrever parece agir sozinha, sendo ela mesma força criadora. Desde esse primeiro momento, a escrita em si, a palavra, suas diversas origens e funções parecem ser perseguidas pela escritora ao longo de toda sua obra, sempre aparecendo representadas através de imagens.

\section{O método de se revelar imagens}

Embora a presente pesquisa tenha como ponto de partida o estudo realizado em A imagistica de Shakespeare (2006), o capítulo do livro de Spurgeon que daria conta de explicitar as técnicas empregadas, intitulado "O objetivo e o método explicados", não cumpre o anunciado. Nele, são apontados somente os objetivos e um conceito geral do que foi considerado como imagem. Toda técnica de coleta de citações, critérios de categorizações e desambiguações não é retratada.

Sendo assim, como forma de garantir a validade deste trabalho, bem como de configurar uma metodologia que poderá servir de base para futuros estudos com os mesmos fins, recorre-se aqui ao processo desenvolvido por Laurence Bardin e publicado em 1977, sob o título de Análise de conteúdo:

A análise de conteúdo é um conjunto de técnicas de análise das comunicações.

Não se trata de um instrumento, mas de um leque de apetrechos; ou, com maior rigor, será um único instrumento, mas marcado por uma grande disparidade de formas e adaptável a um campo de aplicação muito vasto: as comunicações (BARDIN, 2011, p. 31).

Como evidencia a autora, o método proposto não é fixo, podendo ser maleável de acordo com o contexto e o corpus ao qual se aplica. Sendo assim, a Análise de Conteúdo servirá como modelo para a metodologia descrita aqui, permitindo algumas adequações dos passos necessários. 
A primeira fase é conhecida como pré-análise. Segundo Bardin (2011, p. 89), esse é o momento de organização da pesquisa e tem como objetivo tornar operacionais e sistematizar as ideias iniciais, elaborando um esquema sucessivo que permita a análise:

Geralmente, esta primeira fase possui três missões: a escolha dos documentos a serem submetidos à análise, a formulação das hipóteses e dos objetivos e a elaboração de indicadores que fundamentem a interpretação final.

Esses três factores não se sucedem, obrigatoriamente, segundo uma ordem cronológica, embora se mantenham estreitamente ligados uns aos outros: a escolha de documentos depende dos objetivos, ou, inversamente, o objetivo só é possível em função dos documentos disponíveis, os indicadores serão construídos em função das hipóteses ou pelo contrário, as hipóteses serão criadas na presença de certos índices (BARDIN, 2011, p. 89-90, grifo da autora).

Pela flexibilidade possível, o primeiro passo foi estabelecer os objetivos da pesquisa, que partiram de uma identificação das razões para a escrita ficcional. Para atingir tal objetivo, era essencial escolher como fonte documental um escritor que expressasse a questão da escrita de maneira substancial no decorrer de sua obra. Assim, escolheu-se Clarice Lispector como ponto de partida e suas imagens sobre a escrita como recorte.

Devido a este recorte e ao objetivo específico de analisar como a escrita ganharia espaço como temática da autora, realizou-se, incialmente, a análise dos romances Perto do coração selvagem e Um sopro de vida: pulsações, devido a suas posições nos extremos cronológicos da produção de Lispector.

Tal amostra atende à regra de Bardin (2011, p. 90-91) quanto à representatividade, permitindo uma visão considerável para representar os pensamentos de Lispector sobre a criação. Além disso, a homogeneidade é assegurada porque não há singularidades para se efetuar a análise de nenhum dos elementos da pesquisa. Quanto à pertinência, de fato, foi ela que motivou a escolha das duas obras de Lispector como objeto de investigação.

Ainda como pré-análise, deu-se andamento à preparação do material, na qual as obras necessárias foram reunidas, a fim de que se iniciasse a leitura flutuante, que consiste, segundo Bardin, em "estabelecer contacto com os documentos a analisar e em conhecer o texto deixando-se invadir por impressões e orientações" (2011 p. 90).

Em resumo, após a definição do objetivo, as etapas de pré-análise consistiram em: escolha e constituição do corpus, leitura das obras em ordem cronológica e grifo das imagens que seriam analisadas. Após essa etapa, deu-se seguimento à exploração do material, ou seja, à codificação que corresponde, segundo Bardin, a

[...] uma transformação - efectuada segundo regras precisas - dos dados em bruto do texto, transformação esta que, por recorte, agregação e enumeração, permite atingir uma representação do conteúdo (2011, p. 97).

Para isso, o primeiro passo foi a digitação de todas as passagens grifadas nos livros, acompanhadas de índices que 
as tornavam localizáveis, como o título da obra e o número da página. Além disso, começaram a ser estabelecidas as categoriais e subcategorias às quais as passagens se relacionavam.

Sobre a delimitação textual dessas passagens, é essencial destacar que havia muitos critérios possíveis de serem considerados, como elucida Bardin:

A unidade de registro pode ser de natureza e de dimensões muito variáveis. Reina uma certa ambigüidade no concernente aos critérios de distinção das unidades de registro. Efectivamente, executam-se certos recortes a nível semântico, o "tema", por exemplo, enquanto que outros se efectuam a um nível aparentemente linguístico, como por exemplo a "palavra" ou a "frase" (2011, p. 98).

Por ser a escrita de Lispector tão simbólica, se a análise se restringisse ao nível lexical, muitas das imagens se perderiam. Como exemplo, é possível citar os trechos em que, no livro Perto do coração selvagem, Joana inventa histórias para as meninas do internato e para o seu amante. Embora as passagens não sejam ligadas, essencialmente, à escrita, elas o são à criação literária. E mais: evidenciam um importante traço que liga, como se verá posteriormente, a escrita ao universo masculino e a contação ao feminino.

Por exemplos como esse, o recorte feito foi temático. Sobre a extensão dos recortes, ela também poderia ser feita de distintas maneiras, optando pela frase, pelo parágrafo ou pelo contexto. Por se tratar de uma obra literária e com uma complexidade aparente, muitas imagens não se sustentariam sem o amparo do seu contexto original. Por isso, considerou-se como critério destacar todo o trecho que fosse necessário para compreender uma só imagem específica.

Como exemplo, pode-se citar a seguinte passagem, na qual a imagem está retida em uma só frase, mas cujo entorno é que lhe garante a compreensão:

Martim estava de algum modo humilde, se era ser humilde o modo involuntariamente triunfante como estava montado num cavalo - o que lhe dava altura e espanto e determinação e visão mais larga. Nessa inesperada humildade ele pareceu reconhecer mais um sinal de que estava emergindo porque só os animais eram orgulhosos, e só um homem também era humilde. Também a essa coisa indefesa e no entanto audaciosa ele quis dar um nome, mas não existia.

De algum modo foi bom que não existisse: não encontrar um nome aumentou imperceptivelmente a inquietação de que ele agora gozava (LISPECTOR, 1992, p. 114, grifo nosso).

A frase grifada é uma imagem que representa a impossibilidade de se expressar através da língua. Só a unidade de contexto garante uma compreensão de quem quer se expressar, do que se quer dizer e de qual é o reflexo dessa impossibilidade.

Elucidado esse ponto, todos os recortes foram digitados utilizando o programa Excel 2016, que, em suas planilhas, permite filtrar os dados desejados segundo um ou mais critérios informados pelo usuário. Assim, é possível verificar em um ano específico quantas imagens aparecem relacionadas à escrita como catarse, por exemplo. Para isso, cada citação mereceu especial atenção, sendo elencados os itens demonstrados no Quadro 1: 
Quadro 1 - Exemplo de tabulação das imagens

\begin{tabular}{|c|c|c|}
\hline ANO & 1943 & 1978 \\
\hline LIVRO & Perto do coração selvagem & $\begin{array}{l}\text { Um sopro de vida: pul- } \\
\text { sações }\end{array}$ \\
\hline PÁGINA & 124 & 21 \\
\hline PALAVRA-CHAVE & Escrita & Escrita \\
\hline CATEGORIA & Demiurgia & Catarse \\
\hline CITAÇÃO & $\begin{array}{l}\text { Uma folha de caderno intercalava suas páginas. } \\
\text { Olhou-a e descobriu a letra incerta de Joana. } \\
\text { Inclinou-se com avidez. "A beleza das palavras: } \\
\text { natureza abstrata de Deus. É como ouvir Bach." } \\
\text { Por que preferia que ela não tivesse escrito essa } \\
\text { frase? (LISPECTOR, 1998b, p. 124). }\end{array}$ & $\begin{array}{l}\text { Eu escrevo e assim me li- } \\
\text { vro de mim e posso então } \\
\text { descansar (LISPECTOR, } \\
\text { 1999, p. } 21 \text { ). }\end{array}$ \\
\hline COMENTÁRIO & $\begin{array}{l}\text { Este é o único momento do romance em que } \\
\text { aparece a escrita de uma mulher (se não con- } \\
\text { siderarmos como tal alguns bilhetes ocasionais } \\
\text { e de sentido meramente prático, como o de } \\
\text { Lídia, marcando encontro com Joana). No mais, } \\
\text { Otávio se ressente por Joana embrenhar-se } \\
\text { nos seus domínios, tanto da escrita quanto de } \\
\text { Spinoza. Reforça-se a ideia de que a criação } \\
\text { escrita pertence aos homens, não às mulheres. }\end{array}$ & $\begin{array}{l}\text { Quando Autor propõe a } \\
\text { criação da personagem } \\
\text { Ângela Pralini, ela aparece } \\
\text { como uma espécie de ca- } \\
\text { tarse dele mesmo. Como } \\
\text { se só com o esvaziamento } \\
\text { de si mesmo, causado pela } \\
\text { escrita, ele pudesse ter } \\
\text { qualquer descanso. }\end{array}$ \\
\hline
\end{tabular}

Fonte: elaborado pelos autores.

O ano é um critério importante para observar a evolução cronológica da temática. O livro e o número de página ajudam a localizar as citações em futuras consultas. As categorias foram definidas no percurso do trabalho, conforme a recorrência das imagens se apresentava, estabelecendo como critério o contexto e o que era expresso de maneira conotativa ou denotativa em cada uma das imagens. A citação manteve-se fiel à original, respeitando pontuação, grafia, espaçamento e todos os demais itens exigidos em um trabalho científico. O comentário acerca de cada uma foi incluído pelos pesqui- sadores para facilitar o passo seguinte, de análise.

Antes, porém, de tratar da análise, é essencial esclarecer o sistema de categorização que, segundo Bardin, pode ser definido do seguinte modo:

A categorização é uma operação de classificação de elementos constitutivos de um conjunto, por diferenciação e, seguidamente, por reagrupamento segundo o género (analogia), com os critérios previamente definidos. As categorias são rubricas ou classes, que reúnem um certo grupo de elementos (unidades de registro, no caso de análise de conteúdo) sob um título genérico, agrupamento esse efectuado em razão dos caracteres comuns destes elementos (2011, p. 111, grifo da autora). 
Como critério de categorização utilizou-se o semântico. Assim, através do sentido percebido em cada citação, atribuiu-se uma significação inclinada para um ou outro grupo de imagens. É importante destacar que tais grupos não foram definidos previamente, uma vez que dependiam muito de como as imagens fossem reincidindo na obra de Lispector.

Sem dúvida, todos os procedimentos anteriores é que garantiram a chegada na Análise de Conteúdo propriamente dita. Segundo Bardin, é ela quem

fornece informações suplementares ao leitor crítico de uma mensagem, seja este linguista, psicólogo, sociólogo, crítico literário, historiador, exegeta religioso ou leitor profano desejando distanciar-se da sua leitura “aderente", para saber mais sobre esse texto (2011, p. 127).

De fato, para saber mais sobre a representação da escrita em Lispector, o presente artigo faz mais do que conjecturas ilustradas com suas citações. $\mathrm{O}$ levantamento, a tabulação e a categorização de todas as imagens sobre a escrita presentes na ficção da autora são capazes de revelar não só qualitativa como também quantitativamente os resultados que serão referidos na próxima seção.

Para compor a análise quantitativa, que se fundamenta na frequência de aparição de certos elementos no texto, foi necessário realizar uma operação estatística que considerasse os dados elencados. O primeiro levantamento tinha como objetivo verificar como a temática da escrita progrediu cronologicamente ao longo da obra de Lispector. A seguinte, qual das categorias de escrita adquiria maior relevância se comparada às outras. A indicação dessa prevalência estabelece, em grande parte, o que a criação, de fato, representava para a escritora. Com as categorias definidas e sua representatividade destacada, a mais frequente delas foi explorada com base nas teorias que dessem conta de elucidar sua concepção.

Sendo assim, a etapa de análise considerou os seguintes procedimentos: levantamento estatístico da relevância de cada categoria na obra de Lispector e da sua consequente evolução cronológica; elaboração de gráficos que facilitassem a visualização dos dados encontrados; pesquisa de teorias que embasassem as representações elencadas; tratamento dos resultados; e interpretações, apresentadas no capítulo a seguir.

\section{A imagística da escrita em Lispector}

Todo percurso metodológico traçado anteriormente foi capaz de reunir as citações sobre a criação literária presentes tanto na obra Perto do coração selvagem, quanto na Um sopro de vida: pulsações. Ao decorrer da análise, a maior dificuldade encontrada foi, justamente, a categorização destas imagens. Como a própria Lispector escreveu: "Inútil querer me classificar, eu simplesmente escapulo não deixando" (1998a, p. 67). Para superar tal dificuldade, foi necessário observar o tema central em cada 
trecho recortado, resolvendo possíveis ambiguidades e creditando sempre ao assunto predominante a citação anali- sada. Graças a este processo, chegou-se às categorias listadas no Quadro 2, por ordem de frequência.

Quadro 2 - Categorias e frequências das citações

\begin{tabular}{|c|c|c|c|}
\hline Categorias & Perto do coração selvagem & Um sopro de vida: pulsações & TOTAL \\
\hline Demiurgia & 24 & 172 & 196 \\
\hline Impossibilidade & 7 & 54 & 61 \\
\hline Anamnese & 6 & 41 & 47 \\
\hline Sinestesia & 2 & 34 & 36 \\
\hline Catarse & 1 & 27 & 28 \\
\hline Angústia & 1 & 19 & 20 \\
\hline Inspiração & 2 & 13 & 15 \\
\hline Técnica & 3 & 8 & 11 \\
\hline Flow & 0 & 6 & 6 \\
\hline Loucura & 0 & 6 & 6 \\
\hline Imposição & 0 & 4 & 4 \\
\hline Mimese & 0 & 4 & 4 \\
\hline Totais & 46 & 387 & 433 \\
\hline
\end{tabular}

Fonte: elaborado pelos autores.

Sobre as categorias, na primeira delas, Demiurgia, incluem-se todas as metáforas e comparações que ligam o ato de criar com a criação feita por Deus, segundo o livro Gênesis, pertencente à Bíblia e à Torá. A Impossibilidade dá conta de todos os trechos em que a expressão por meio das palavras parece ser ineficiente, resultando na frustração ou no silêncio. Por Anamnese, adotou-se o conceito psicanalítico da escrita como forma de autoconhecimento, revelações que partem do autor para o próprio autor e surpreendem-no. Sob o título de Sinestesia, foram reunidas as imagens que ligavam a escrita a sensações, sons, gostos ou elementos perceptíveis por sentidos diferentes da visão. O termo Catarse recorre ao conceito aristotélico da purgação de sentimentos resultante da apreciação de uma obra artística. Em Lispector, porém, a catarse ocorre no momento da criação, e suas metáforas podem ser ligadas ao aspecto físico, espiritual ou psíquico.

A categoria Angústia representa a escrita como um fardo, uma obrigação, capaz de gerar tormentos e dores em quem a executa. Já a Inspiração retoma o ideal romântico de uma criação cuja 
origem está em um impulso misterioso. Sob a alcunha de Técnica reuniram-se os trechos em que a escrita aparece despida de qualquer metáfora ou reflexão, sendo puramente mecânica ou autômata. O Flow (ou fluxo) baseia-se no conceito elaborado pelo psicólogo Mihaly Csikszentmihalyi (1999), que consiste na abstração da realidade, vivida pelo artista no momento criador. A Loucura não poderia deixar de ser uma temática presente também na escrita, uma vez que ela encontra outras ressonâncias na obra de Lispector. Contrastando com a inspiração, há momentos em que a criação aparece como Imposição, como se o leitor obrigasse Lispector a continuar. Por fim, a Mimese, tal como no conceito platônico, também é referida, inclusive com a metáfora das sombras aparecendo em um dos seus trechos.

Elucidadas as categorias, o que primeiro se pode observar é a confirmação da hipótese de que o tema ganhou relevância ao longo da obra de Lispector. Em seu romance inaugural, foram coletadas 46 citações sobre a criação literária, o que totalizou 2.922 palavras. De certa forma, pode-se dizer que apenas $6 \%$ do livro, cujo número total de palavras é 48.193, trata sobre a escrita e suas metáforas. Uma busca textual corrobora com essa afirmação. O radical "escr" pode ser encontrado apenas 17 vezes ao longo do texto, sendo representado nas outras citações por metáforas ou palavras afins.

Por outro lado, ao se analisar Um sopro de vida: pulsações, lançado 34 anos depois, percebe-se que o tema ocupa $38 \%$ do livro. São, ao todo, 387 citações, que resultam em 15.494 palavras, de um total de 41.178. Do mesmo modo, o radical "escr" tem uma frequência de aparição bem mais relevante: 231 vezes. Nos Gráficos 1 e 2, é possível visualizar a proporção com que a temática aparece em cada obra.

Gráfico 1 - A criação literária em Perto do Coração Selvagem

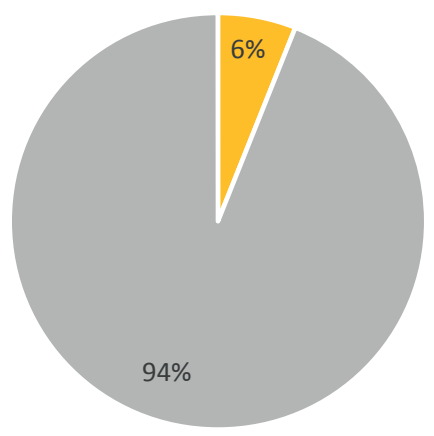

- Citações sobre a criação artística - Demais temas

Fonte: elaborado pelos autores.

Gráfico 2 - A criação literária em Um sopro de vida: pulsações

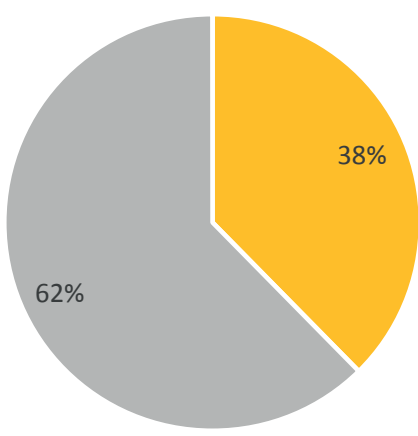

- Citações sobre a criação artística m Demais temas Fonte: elaborad pelos autores. 
Apesar dessa diferença, é importante ressaltar que a escrita é temática recorrente não apenas nas duas obras aqui analisadas, como também em todos os demais escritos de Lispector, especialmente em romances e crônicas. O que se observa é apenas o amadurecimento das conjecturas, ou seja, uma maior preocupação, ao decorrer do tempo, com o ofício de escrever. Tal como constata Souza:

A relação com a matéria envolvida no processo da escrita e sua tematização constituem inegável recorrência das obras modernas. Em Clarice Lispector o modo como se manifesta essa obsessão passa pela consciência que em si existe relativamente à "construção" de um trajeto que tende a ser dominado na sua curva descendente pelos impulsos do desvelamento. A intensidade com que ela se entrega às questões levantadas pelo ato de procura na escrita suscita ao leitor uma tentativa de ordenar aquilo que se oferece como constituindo o funcionamento do mundo textual clariciano (2012, p. 421-422).

Nesta tentativa de ordenar as questões levantadas por Lispector, é fundamental ainda observar que, embora em quantidades diferentes, as proporções com que cada categoria definida aparece nas obras são muito semelhantes. Assim, guardadas as frequências, as razões para a criação literária que instigavam a autora no início de sua carreira continuavam a persegui-la ao final dela, como se pode observar no Gráfico 3.

Gráfico 3 - Comparação de frequência temática entre as duas obras

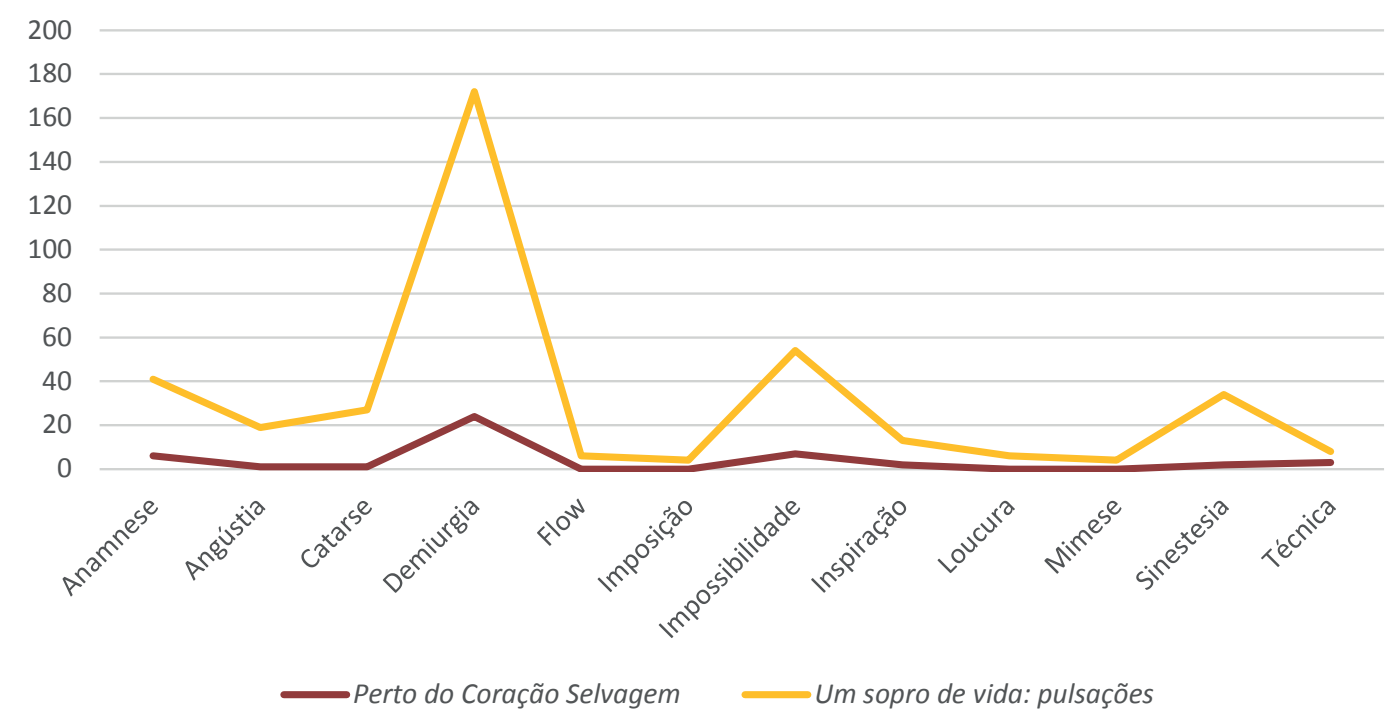

Fonte: elaborado pelos autores. 
Ao comparar as duas linhas formadas pela frequência com que cada categoria aparece em ambas as obras, é possível perceber que elas traçam praticamente $o$ mesmo desenho de picos e vales. Ou seja, a temática mais relevante apresentada em Um sopro de vida: pulsações já era evidentemente dominante em Perto do coração selvagem.

Assim, é possível estabelecer que, de modo geral, a categoria predominante nas imagens de escrita de Lispector é a criação literária como Demiurgia, ou seja, análoga ao engendramento do mundo feito por Deus segundo as religiões cristãs e judaicas. Para explicitar, pode-se recorrer à própria Lispector: "O que a nossa imaginação cria se parece com o processo que Deus tem de criar" (1999, p. 135). Desta forma, no Gráfico 4 , é possível visualizar essa predominância, bem como a representatividade das demais categorias no somatório das duas obras.

Gráfico 4 - Representatividade total de cada categoria

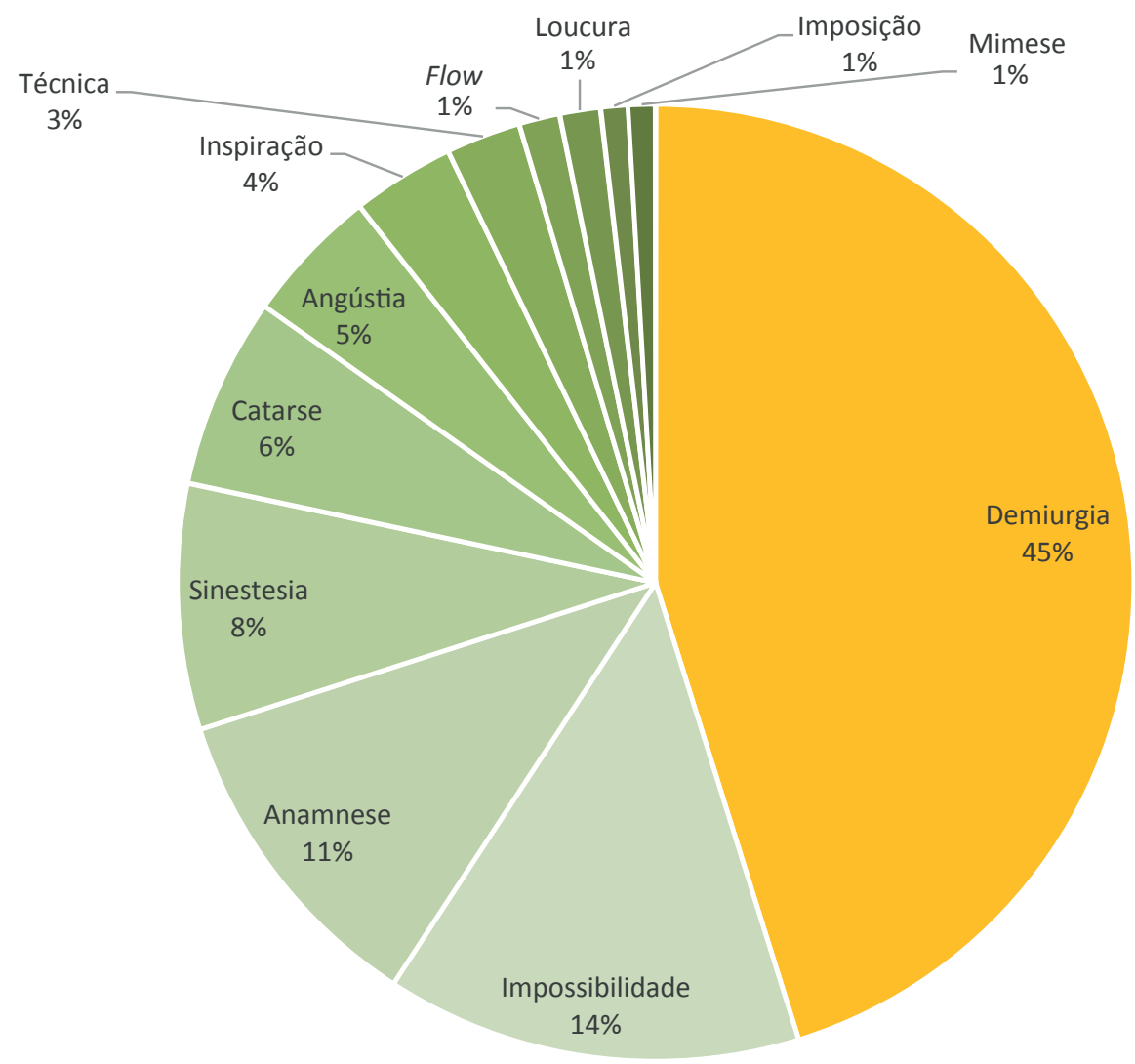

Fonte: elaborado pelos autores. 
Como descrito anteriormente, devido à extensão deste artigo, apenas uma das categorias será aqui analisada. Obviamente a escolha se dará devido à prevalência desta imagem sobre as demais. Assim, a Demiurgia será esmiuçada a seguir como representação da criação literária.

\section{À imagem de Deus}

A Bíblia, palavra cujo significado grego é "rolo" ou "livro", foi o maior best-seller já escrito na história da humanidade e, completa ou em partes, instaurou-se como base das maiores crenças ocidentais: o cristianismo e o judaísmo. Para os cristãos, a Bíblia é composta de 66 livros, sendo 39 do Velho Testamento, com narrativas de grandes feitos, e 27 do Novo Testamento, centrados especialmente na vida e nas realizações de Jesus Cristo. Já para os judeus, a Torá, texto sagrado, contém apenas o Pentateuco, os cinco primeiros livros da Bíblia cristã: Gênesis, Êxodo, Levítico, Números e Deuteronômio.

Segundo a biografia escrita por Moser (2009), Lispector era de família judaica, o que a fez desde pequena praticar o estudo da Torá. As referências bíblicas presentes em sua obra são, inclusive, alvo de alguns estudos, como aqueles que ligam o nome de Macabéa aos Macabeus. ${ }^{2}$ Nas obras analisadas aqui, Lispector fixa-se especialmente nos primeiros capítulos de Gênesis e traça um paralelo entre a forma de Deus criar e a forma de um autor escrever.

Na cultura judaico-cristã, a Deus é atribuído o poder da palavra. É assim que começa o relato de sua criação: " $\mathrm{E}$ Deus disse: Faça-se a luz. E foi feita a luz" (BÍBLIA, 2010, p. 16). Nenhum gesto mais se exige de Deus além de proclamar a sentença criadora. Além disso, ele decide como chamar cada uma de suas criações. "E chamou à luz de Dia, e às trevas de Noite" (BÍBLIA, 2010, p. 16), podendo assim dominá-las.

De acordo com esses textos, aqui tomados como literatura, é através da linguagem que Deus concentra seu poder e submete-o aos seus desígnios. Para Lispector, o escritor procede da mesma forma, a partir do instante em que realiza a criação de seres ficcionais. Segundo Brait, as personagens não são apenas "papel pintado com tinta" (1985, p. 11-12). Apesar de diferirem da matéria e do espaço habitado pelos seres humanos reais, elas adquirem vida plena no mundo ficcional, a ponto de povoarem $o$ plano imaginário do leitor:

Como um bruxo que vai dosando poções que se misturam num mágico caldeirão, o escritor recorre aos artifícios oferecidos por um código a fim de engendrar suas criaturas. Quer elas seja tiradas de sua vivência real ou imaginária, dos sonhos, dos pesadelos ou das mesquinharias do cotidiano, a materialidade desses seres só pode ser atingida através de um jogo de linguagem que torna tangível a sua presença e sensíveis os seus movimentos (BRAIT, 1985, p. 53).

Bruxo ou Deus, é indiscutível o poder anímico do escritor que, através das pa- 
lavras, delineia uma criatura ficcional aos olhos do leitor. Enquanto descreve os traços de uma pessoa inventada, forma uma personagem e, quando lhe atribui ações, faz com que ganhe vida. É através dessa tessitura que Lispector experimenta a sensação de ser Deus. Embora todo romancista passe por esse momento de criação, são raros aqueles dispostos a desvelarem esse momento: a feitura de um ser ficcional, termo que até pode parecer contraditório, mas que não o é, segundo Candido:

De fato, como pode uma ficção ser? Como pode existir o que não existe? No entanto, a criação literária repousa sobre este paradoxo, e o problema da verossimilhança no romance depende desta possibilidade de um ser fictício, isto é, algo que, sendo uma criação da fantasia, comunica a impressão da mais lídima verdade existencial. Podemos dizer, portanto, que o romance se baseia, antes de mais nada, num certo tipo de relação entre o ser vivo e o ser fictício, manifestada através da personagem, que é a concretização deste (1976, p. 52).

Assim como o Deus descrito em Gênesis, Lispector também faz o verbo tornar-se carne:

Ângela não é um "personagem". É a evolução de um sentimento. Ela é uma idéia encarnada no ser. No começo só havia a idéia. Depois o verbo veio ao encontro da idéia. E depois o verbo já não era meu: me transcendia, era de todo o mundo, era de Ângela (1999, p. 30).

O próprio título de Um sopro de vida: pulsações remete à ideia bíblica da criação, segundo a qual Deus teria feito o homem de barro e dado nele um sopro de vida. Para isso, Lispector cria sua própria versão: "Estou esculpindo Ângela com pedras das encostas, até formá-la em estátua. Aí sopro nela e ela se anima e me sobrepuja" (1999, p. 30).

A própria noção de que o homem é feito à imagem e semelhança de Deus também é explorada nas metáforas da autora sobre a escrita:

Ângela é a minha tentativa de ser dois. Infelizmente, porém, nós, por força das circunstâncias, nos parecemos e ela também escreve porque só conheço alguma coisa do ato de escrever (LISPECTOR, 1999, p. 30).

Do ponto de vista teórico, a imagem do autor como Deus, capaz de criar por palavras, pode ser elucidada pelas contribuições de Austin para a filosofia da linguagem. Segundo a concepção do estudioso, há um tipo de discurso que não apenas descreve a realidade, mas também a modifica. Assim, a língua deixa de ser mero reflexo do que existe, submetida a uma verificação de verdadeiro e falso, tornando-se um mecanismo de ação.

Segundo Austin,

Por mais tempo que o necessário, os filósofos acreditaram que o papel de uma declaração era tão somente o de "descrever" um estado das coisas, ou declarar um fato, o que deveria fazer de modo verdadeiro ou falso (1990, p. 21).

Certos proferimentos, porém, não pareciam encaixar-se nessa categoria. Afinal, não eram usados para simplesmente registrar ou transmitir uma informação direta.

Através da apurada busca por respostas, Austin chegou à teoria das sentenças performáticas, capazes de produzirem 
uma alteração no universo real. Para que tais sentenças se cumpram são necessárias algumas condições:

A. que nada "descrevam" nem "relatem", nem constatem e nem sejam verdadeiras ou falsas.

B. cujo proferimento da sentença é, no todo ou em parte, a realização de uma ação que seria normalmente descrita consistindo em dizer algo (AUSTIN, 1990, p. 24).

Como exemplo dessas sentenças performáticas, Austin expõe o caso de um padre que, ao dizer durante a cerimônia de batizado "Eu te batizo em nome do Pai, do Filho e do Espírito Santo", não está simplesmente declarando algo, mas realizando uma transformação na realidade: a de converter uma criança pagã em cristã.

Proposta e explicada de forma prática essa primeira etapa, Austin cria certas condições para que um performático seja considerado como feliz. ${ }^{3}$ A primeira delas é a de que:

É sempre necessário que as circunstâncias em que as palavras forem proferidas sejam, de algum modo, apropriadas; frequentemente é necessário que o próprio falante, ou outras pessoas, também realize determinadas ações de certo tipo, quer sejam ações "físicas" ou "mentais", ou mesmo o proferimento de algumas palavras adicionais (AUSTIN, 1990, p. 26, grifo do autor).

Embora a teoria de Austin aplique-se primordialmente à fala e a ações concretas, é possível encaixar em seus requisitos as sentenças usadas na criação de uma obra literária. Como bem afirma Willemart, "a criação em si é instantânea e obedece imediatamente à palavra. Deus, tanto quanto o artista, não traba- lha, mas cria" (1999, p. 69). Assim, toda criação literária e ficcional não é mera descrição ou relato de algo que aconteceu, que pode ser submetido ao critério de verdadeiro ou falso. A ficção está além de tais conceitos. Uma obra pode ou não ser verossímil, ainda assim, não se trata de uma descrição ou constatação.

Da mesma forma, conforme vai sendo escrita e estruturada, a história contada passa a ser criada dentro de um universo ficcional. No momento em que o autor escreve algo como "Martha nasceu na primavera de 1967", ele não faz outra coisa senão dar vida para uma mulher chamada Martha que existirá dentro dos limites de sua escrita.

Assim, promove-se também a modificação em uma determinada realidade, pela criação de algo que, até então, não existia:

Não são mais as palavras que constituem as personagens e seu ambiente. São as personagens (e o mundo fictício de cena) que "absorveram" as palavras do texto e passam a constituí-las, tornando-se a fonte delas - exatamente como ocorre na realidade (CANDIDO, 1976, p. 29).

Austin afirma ainda que para acontecer uma transformação através das palavras:

(A.1) Deve existir um procedimento convencionalmente aceito, que apresente um determinado efeito convencional e que inclua o proferimento de certas palavras por certas pessoas, e em certas circunstâncias; e além disso que

(A.2) as pessoas e circunstâncias particulares, em cada caso, devem ser adequadas ao procedimento específico invocado (1990, p. 31). 
A contação de histórias e a escrita ficcional são, sem dúvida, procedimentos convencionalmente aceitos. Todas as culturas possuem suas próprias histórias e fábulas, do mesmo modo que possuem seus escritores, contadores, ouvintes e leitores. Como pessoas adequadas, têm-se as figuras do escritor, considerado autorizado a criar histórias, e do leitor, sem o qual tais histórias não ganham concretude.

Dessa forma, o autor é capaz de criar um universo ficcional do mesmo modo como um padre é capaz de transformar um pagão em cristão ou Deus é capaz de criar o mundo: pelo uso da palavra.

Em Um sopro de vida: pulsações, Lispector deixa evidente essa relação entre a linguagem, usada como performance, e a vida de um ser ficcional no momento em que escreve: "Ângela parte da linguagem à existência. Ela não existiria se não houvesse palavras" (LISPECTOR, 1999, p. 83).

A unidade entre o escrever e o fazer está igualmente evidenciada no momento em que sua personagem pensa em ter um filho e faz a seguinte fala: "Eu gosto tanto de crianças, eu gostaria tanto de publicar um filho chamado João!" (LISPECTOR, 1999, p. 98). Como Ângela é feita de palavras, fazer nascer um filho não seria diferente de publicá-lo, ou seja, de executar uma sentença performática.

De fato, sem o uso das palavras nenhuma ficção poderia existir, o que permite que todos os critérios para a realização de performáticos felizes sejam aplicados para a relação escritor- -obra-leitor em textos ficcionais. A obra, assim, torna-se uma realidade concretizada no momento em que é escrita e lida. Por isso o pedido de Lispector de:

Não ler o que escrevo como se fosse um leitor. A menos que esse leitor trabalhasse, ele também, nos solilóquios do escuro irracional (1999, p. 21).

Segundo Ingarden (1979), cabe ao leitor entrar em contato com o texto e seguir por ele a ponto de concretizar a vida imaginária das personagens cerzidas pelo autor. Sem o leitor, as palavras não conseguem completar seu ciclo, esbarrando no procedimento específico que deveria ter sido invocado.

Quando bem criada e construída, a personagem chega a extrapolar as barreiras do mundo ficcional, tomando uma espécie de materialidade diante do leitor. De onde vem esse ser capaz de emocionar, de ensinar, de conviver até mesmo com o leitor? Das palavras de um autor demiurgo:

Uma coisa que se pensava não existia antes de se pensar. Por exemplo, assim: a marca dos dedos de Gustavo. Isso não vivia antes de se dizer: a marca dos dedos de Gustavo... $\mathrm{O}$ que se pensava passava a ser pensado. Mais ainda: nem todas as coisas que se pensavam passavam a existir daí em diante... Porque se eu digo: titia almoça com titio, eu não faço nada viver. Ou mesmo se eu resolvo: vou passear; é bom, passeio... e nada existe. Mas se eu digo, por exemplo: flores em cima do túmulo, pronto! eis uma coisa que não existia antes de eu pensar flores em cima do túmulo (LISPECTOR, 1998b, p. 138).

Percebe-se aqui um progresso ainda anterior ao descrito na Bíblia, para 
explicar a criação literária. Antes da realidade, é preciso haver a palavra e o que a precede é ainda o pensamento. Nesse sentido, o trecho de Lispector corrobora com o que afirma Cassirer sobre a mitologia da linguagem:

Aqui, como já houve quem acentuasse, concebe-se, milhares de anos antes da era cristã, Deus como um Ser espiritual, que pensou o mundo antes de criá-lo e usou a Palavra como meio de expressão e instrumento de criação (2009, p. 65).

A linguagem seria, portanto, mágica a ponto de materializar o pensamento. Assim como para Deus, o poder criador das palavras seria infinito para o autor. Cidades, ambientes, objetos e pessoas não precisam mais do que ser descritos para adquirirem uma materialidade ficcional. Depois de inventados e insuflados de vida, tudo que o autor criou permanece sob seu domínio. Ele é quem determina os fatos, atribui as falas, dá destino ao enredo. Da mesma forma que com um aglomerado de letras fez cada elemento da narrativa, o escritor pode, com outras palavras, extingui-los:

A Palavra se converte numa espécie de arquipotência, onde radica todo o ser e todo acontecer. Em todas as cosmogonias místicas, por mais longe que remontemos em sua história, sempre volvemos a deparar com esta posição suprema da Palavra. [...] Nos relatos da Criação de quase todas as grandes religiões culturais, a Palavra aparece sempre unida ao mais alto Deus criador, quer se apresente como instrumento utilizado por ele, quer diretamente como fundamento primário de onde ele próprio, assim como toda existência e toda ordem de existência provêm (CASSIRER, 2009, p. 64-65).
É esta arquipotência que Lispector procura em sua produção. Profundamente imiscuída na mitologia judaico-cristã, a autora busca através de suas imagens sobre a escrita aproximar o seu processo de criação ao de Deus: "AUTOR.- Quando Ângela pensa em Deus, será que ela se refere a Deus ou a mim?" (LISPECTOR, 1999, p. 126).

Desta forma, a palavra como potência criadora, o controle sobre suas personagens, o nome secreto de Deus, estudado pela mitologia judaica, e o nome "Autor" em Um sopro de vida: pulsações, tudo converge para escrita como apropriação dos poderes divinos. Talvez, seja esta uma tentativa de Lispector alcançar e compreender Deus, uma vez que também Ele é seu tema recorrente.

\section{Considerações finais}

Ainda na infância, fabular tornou-se natural para Lispector. Passado o pasmo de descobrir que os livros não nasciam como bichos ou plantas, a menina decidiu tomar para si a tarefa de compor histórias. Já nesse início, a escritora adquiriu consciência da magia por dentro das palavras. Nos seus contos, mortos podiam ressuscitar, e finais podiam ser eternamente reescritos, dependendo para isso apenas de alguns vocábulos.

Anos depois, durante sua jornada como escritora, buscar o sentido da criação literária, compreender os mistérios das palavras e o poder que tratava de aproximar o homem de Deus parecem ter sido o norte maior de sua composição literária. 
De fato, em 433 passagens dos dois livros analisados, Deus e homem aparecem ora como equivalentes, ora como antagônicos, sobrepujados um pelo outro quanto à matéria da criação. Nessa exploração e aproximação do divino, Lispector não quer alcançar esse Deus de forma mística, iluminada e religiosa, ela quer é compreendê-lo dentro das limitações humanas. Para isso, Lispector passa a ser Deus, criando como Ele suas personagens e controlando-as o melhor que pode.

De uma escritora cujas obras foram pautadas por essa experimentação de Deus, é natural esperar sondagens cada vez mais profundas e reveladoras sobre a criação. Embora essa temática da criação, especialmente a literária - para ela análoga à divina -, já viesse sendo explorada por Lispector desde suas primeiras composições, é em Um sopro de vida: pulsações que a escritora parece chegar mais perto do que pretendia.

Nesse livro, fragmentário e complexo, toda história é desligada em nome de um objetivo maior: desvelar a própria tessitura, coisa que Lispector consegue como ninguém. Colocada no nada absoluto e disfarçada pela máscara de uma personagem sem nome próprio, Lispector é capaz de, finalmente, encarnar Deus, para compreendê-Lo e, assim, compreender a si mesma.

Usando a palavra, tal qual Deus na mitologia do gênesis, Lispector é capaz de compor sua própria versão do mito da criação. No lugar de Adão e Eva estão suas personagens, como a responsável pela tentação, em vez da serpente e do fruto proibido, há a própria escrita e sua representação, condutoras do pecado maior: a soberba de tentar igualar-se a Deus.

\section{The imagery of writing at the extremes of Clarice Lispector's work}

\begin{abstract}
This paper has as its base the Shakespeare's Imagery piece by Caroline Spurgeon (2006), whose purpose was to gather, catalog and analyze all the metaphors present in the work of the classic English writer. In this case, however, we will analyze the metaphors, similes, comparisons and references observed in the writing and literary creation presented in two extreme productions of Clarice Lispector. That is, it will be considered Near to the Wild Heart (1998b), first published in 1964, and A breath of Life (1999), first published in 1978. For this, the method of the Content Analysis, developed by Bardin (2011), in which textual analysis is done quantitatively and qualitatively, will be used. In this fashion, the literary images are tagged, gathered, categorized and weighted according to their frequency of appearance. The objective is to verify how literary creation has progressed throughout the author's production. In addition, this paper explores the representation which has greater relevance for Lispector: demiurgy, treated here based on theories of Austin (1990) and Cassirer (2009).
\end{abstract}

Keywords: Content Analysis. Demiurgy. Genesis. Literary Creation. 


\section{Notas}

1 Para Paz, o conceito de poesia é complexo e abstrato, só podendo ser explicado também por meio de imagens: "A poesia é conhecimento, salvação, poder, abandono. Operação capaz de transformar o mundo, a atividade poética é revolucionária por natureza; exercício espiritual, é um método de libertação interior. A poesia revela este mundo; cria outro. Pão dos eleitos. Alimento maldito. Isola; une. Convite à viagem; regresso à terra natal. Inspiração, respiração, exercício muscular. Súplica ao vazio, diálogo com a ausência, é alimentada pelo tédio, pela angústia e pelo desespero. Oração, litania, epifania, presença. Exorcismo, conjuro, magia. Sublimação, compensação, condensação do inconsciente" (1982, p. 15-16).

2 Recomenda-se para leitura o artigo "A travessia cultural de Macabéa" (2006), de

3 Para Austin (1990), o performático feliz é aquele que, além de passar pelos critérios de adequação por ele formatados, produz, ao ser dito, uma modificação na realidade.

\section{Referências}

AUSTIN, John Langshaw. Quando dizer é fazer. Porto Alegre: Artes Médicas, 1990.

BACHELARD, Gaston. A poética do devaneio. São Paulo: Martins Fontes, 1988.

BARDIN, Laurence. Análise de conteúdo. Lisboa: Edições 70, 2011.

BÍBLIA SAGRADA. São Paulo: DCL, 2010.

BRAIT, Beth. A personagem. São Paulo: Ática, 1985.

CAMPEDELLI, Samira Youssef. Clarice Lispector. São Paulo: Abril Educação, 1981.

CANDIDO, Antonio et al. A personagem de ficção. São Paulo: Perspectiva, 1976.

CASSIRER, Ernst. Linguagem e mito. São Paulo: Perspectiva, 2009.

CHALHUB, Samira. A metalinguagem. São Paulo: Ática, 1988.
COUTINHO, Afrânio (Dir.). A literatura no Brasil: era modernista. 5. ed. São Paulo: Global, 1999.

CSIKSZENTMIHALYI, Mihaly. A descoberta do fluxo: a psicologia do envolvimento com a vida cotidiana. Rio de Janeiro: Rocco, 1999.

INGARDEN, Roman. A obra de arte literária. Lisboa: Fundação Calouste Gulbenkian, 1979.

LISPECTOR, Clarice. A maçã no escuro. Rio de Janeiro: Francisco Alves, 1992.

1998a.

Água viva. Rio de Janeiro: Rocco,

. Perto do coração selvagem. Rio de Janeiro: Rocco, 1998b.

Um sopro de vida: pulsações. Rio de Janeiro: Rocco, 1999.

MOISÉS, Massaud. História da literatura brasileira: modernismo. 6. ed. São Paulo: Cultrix, 2004.

MOSER, Benjamin. Clarice,. São Paulo: Cosac Naify, 2009.

NOLASCO, Edgar Cézar. A travessia cultural de Macabéa. In: OLIVEIRA, Dercir Pedro de (Org.). O livro da concentração: o linguístico e o literário. Campo Grande, MS: Editora da UFMS, 2006. p. 119-129.

NOVELLO, Nicolino. O ato criador de Clarice Lispector. Rio de Janeiro: Presença, 1987.

PAZ, Octávio. O arco e a lira. Rio de Janeiro: Nova Fronteira, 1982.

SOUZA, Carlos Mendes de. Clarice Lispector: figuras de escrita. São Paulo: Instituto Moreira Sales, 2012.

SPURGEON, Caroline. A imagística de Shakespeare. São Paulo: Martins Fontes, 2006.

WILLEMART, Philippe. Bastidores da criação literária. São Paulo: Iluminuras, 1999. 